\title{
Liquefaction of hydrothermally pretreated wheat straw at high-solids content by purified Trichoderma enzymes
}

\section{Szijarto, Nora}

2011-01

Szijarto , N , Siika-Aho , M , Sontag-Strohm , T \& Viikari , L 2011 , ' Liquefaction of hydrothermally pretreated wheat straw at high-solids content by purified Trichoderma enzymes ' , Bioresource Technology , vol. 102 , no. 2 , pp. 1968-1974 . https://doi.org/10.1016/j.biortech.2010.09.01

http://hdl.handle.net/10138/33312

https://doi.org/10.1016/j.biortech.2010.09.012

submittedVersion

Downloaded from Helda, University of Helsinki institutional repository.

This is an electronic reprint of the original article.

This reprint may differ from the original in pagination and typographic detail.

Please cite the original version. 
Published in: Bioresource Technology, 2011, 102 (2), 1968-1974

\title{
Liquefaction of hydrothermally pretreated wheat straw at high-solids content by purified Trichoderma enzymes
}

\author{
Nóra Szijártó ${ }^{\text {a, }}$, Matti Siika-aho ${ }^{\text {b }}$, Tuula Sontag-Strohm ${ }^{\text {a }}$, Liisa Viikari ${ }^{\text {a }}$ \\ ${ }^{a}$ University of Helsinki, Department of Food and Environmental Sciences, P.O. Box 27, \\ FIN-00014, Helsinki, Finland \\ ${ }^{\mathrm{b}}$ VTT Technical Research Center of Finland, P.O. Box 1000, FIN-02044, Espoo, \\ Finland \\ * Corresponding author. Tel.: +358 9191 57602; Fax: +358 9191 58475, E-mail \\ address: nora.szijarto@helsinki.fi
}

\begin{abstract}
Enzymatic liquefaction was studied by measuring continuously the flowability change of high-solids lignocellulose substrates using a real time viscometric method. Hydrolysis experiments of hydrothermally pretreated wheat straw were carried out with purified enzymes from Trichoderma reesei; Cel7A, Cel6A, Cel7B, Cel5A, Cel12A and Xyn11A. Results obtained at $15 \%$ w/w solids revealed that endoglucanases, in particular Cel5A, are the key enzymes to rapidly reduce the viscosity of lignocellulose substrate. Cellobiohydrolases had only minor and the xylanase practically no effect on the viscosity. Efficient, fast liquefaction was obtained already at a dosage of $1.5 \mathrm{mg}$ of
\end{abstract}


Cel5A per g dry solids. Partial replacement or supplementation of EGII by the other major hydrolytic enzymes did not improve the liquefaction. The reduction of viscosity did not correlate with the saccharification obtained in the same reaction, suggesting that efficient liquefaction is rather dependent on the site than the frequency of enzymatic cleavages.

Keywords: biomass, liquefaction, cellulase, Trichoderma reesei

\section{Abbreviations}

$\mathrm{CBH}$ cellobiohydrolase

DM dry matter

DNS 2,4-dinitrosalicylic acid

EG endoglucanase

FPA filter paper activity

FPU filter paper unit

HEC hydroxyethyl cellulose

MUL 4-methylumbelliferyl- $\beta$ - $D$-lactoside

PNPG $\quad p$-nitrophenyl- $\beta$ - $D$-glucopyranoside

RVA Rapid Visco Analyzer

XYL xylanase

\section{Introduction}


The increasing demand for environmentally benign, secure and competitive transportation fuels has reinforced interest in the production of fuel ethanol from renewable resources. The primary interest is to use lignocellulose biomass as feedstock, preferably wastes and by-products of existing forest or agricultural crop production, not competing with food supplies or with land where food crops can be grown. However, to become economically competitive, the production of lignocellulosic ethanol still needs technological improvements. As the enzyme cost still accounts for a considerable proportion of the total production costs (Hahn-Hägerdal et al., 2006), one obvious target of process optimization is to achieve efficient solubilisation of fermentable sugars from the polysaccharide substrates at reduced enzyme use. Another objective is to increase the final ethanol concentration by using high-solids raw material treatments, most importantly because the costs of down-stream processing are sharply reduced as the product concentration is increased. Distillation can be considered economical if the fermentation broth contains more than 4\% (w/w) ethanol (Zacchi and Axelsson, 1989). To reach an ethanol concentration of higher than $4 \%(\mathrm{w} / \mathrm{w})$, for most types of lignin containing biomasses the initial solids content needs to be above 15\% (Larsen et al., 2008).

Recently, research to develop conversion processes performing enzymatic hydrolysis of lignocelluloses at high substrate concentrations has gained growing interest (Varga et al., 2004; Jørgensen et al., 2007; Georgieva et al., 2008). Although the flowability of these substrates improves as a result of cellulolytic activity, the initially high viscosity of concentrated lignocelluloses currently prevents efficient mixing. Therefore, one of the most important breakthroughs in this area has been the replacement of conventional 
stirring systems with gravimetric mixing, enabling liquefaction, saccharification, and fermentation of pretreated biomass at up to $40 \%$ initial solids content (Jørgensen et al., 2007; Larsen et al., 2008). Enzymatic hydrolysis at high-solids creates new challenges for the enzymes and understanding the rheological behaviour of high-solids raw materials during the enzymatic hydrolysis becomes more important.

To investigate the material properties of high-solids lignocelluloses most authors have used pretreated corn stover as substrate. Using this material at $5-30 \%(\mathrm{w} / \mathrm{w})$ solids and the helical impeller technique as the rheological measurement Pimenova and Hanley (2004) first reported that the suspensions exhibited plastic-type rheological behaviour with an apparent yield stress. Corn stover suspensions (20-35\%) were also studied by using torque rheometry and the shear-thinning behaviour of the substrate was confirmed (Ehrhardt et al., 2009). It was found that the rheological properties of these slurries were well described by the Bingham model, with the yield stress increasing with solids concentration. Also other models, the Casson and the Herschel-Buckley models, have been used for describing the rheology of 10-40\% biomass suspensions (Houchin and Hanley, 2004; Pimenova and Hanley, 2004). The most comprehensive study available to date on the rheology of high-solids biomass suspensions is the recent inter-laboratory report by Stickel et al. (2009). A variety of instruments and tools (vanes, roughened plates and a torque rheometer) at different substrate concentrations up to $30 \%$ insoluble solids were used to measure the rheology of dilute acid treated corn stover. Previously reported characteristics, such as the strongly shear-thinning and viscoelastic behaviour, and concentration-dependent yield stress, were confirmed. In another study the advantages and disadvantages of several rheological techniques (shear-flow using a 
vane, torsional flow between parallel plates, and biaxial extensional flow between plates) using the same substrate were evaluated, concluding that the vane geometry provided the simplest methodology and the most reproducible results (Knutsen and Liberatore, 2009).

To follow the reduction of viscosity during enzymatic hydrolysis, all studies so far have used traditional rheological approaches, i.e. samples collected at specific time points in the hydrolysis reactions have been subjected to various measurements in a separate instrument. Rosgaard et al. (2007) studied the effect of commercial cellulases on the viscosity of 5-15\% (w/w) steam-pretreated barley straw using the vane spindle method and confirmed that the apparent viscosity increased with solids concentration and decreased with time during the enzymatic hydrolysis. Roche et al. (2009) used parallel plate and vane-in-cup geometries to study the rheology of dilute acid pretreated corn stover at solids loadings of $20 \%$, and developed a semi-empirical relationship to connect the progress of enzymatic hydrolysis with particle concentration and yield stress. They concluded that the dominant effect on the rheology of saccharifying biomass was material dilution as the hydrolyzed biomass was transferred from solid to liquid phase. The importance of particle size and shape affecting the rheology has also been recognized using parallel plate (Viamajala et al., 2009) or vane-in-cup systems (Dasari and Berson, 2007).

The current starch-based processes are conducted at substrate loadings as high as $33-37 \%$ dry matter (w/w) (Thomas and Ingledew, 1992) and are initialized with a hightemperature $\left(\sim 90{ }^{\circ} \mathrm{C}\right)$ liquefaction of starch followed by saccharification and 
fermentation carried out at moderate temperatures depending on the temperature optima of the biocatalysts and yeast used. There are several approaches to apply this process concept also for the treatment of lignocellulose biomass (Viikari et al., 2007). The well studied filamentous fungus Trichoderma reesei is one of the most efficient producers of biomass degrading enzymes. Many of the commercially available cellulase preparations suitable for moderate temperatures are produced with this organism. The fungus produces a compliment of cellulases, including two cellobiohydrolases (CBHs) and five endoglucanases (EGs). The goal of the present study was to indentify the key enzyme(s) needed for an efficient liquefaction of high-solids pretreated biomasses. To obtain detailed information on the time course of liquefaction, a new rheological measurement method using a rotational viscometer was developed, which allows real time monitoring of substrate viscosity during the enzymatic action under fully controlled temperatures and agitation rates. In particular, the technique was focused on the early stage of hydrolysis where the changes in the rheological behaviour of high-solids substrates are most pronounced. The developed system was used to evaluate the liquefaction properties of enzymes derived from various glycosyl hydrolase families and possessing different hydrolytic properties.

\section{Materials and Methods}

\subsection{Substrate}

Hydrothermally treated wheat straw (Triticum aestivum L.) obtained from Inbicon A/S (Fredericia, Denmark) was used as the lignocellulose substrate throughout the study. The pretreatment was carried out under previously optimized conditions according to 
Larsen et al. (2008). The feedstock was first pre-soaked in $3 \mathrm{~g} / \mathrm{l}$ acetic acid at $80{ }^{\circ} \mathrm{C}$ for $10 \mathrm{~min}$ and then steamed at $195^{\circ} \mathrm{C}$ for $12 \mathrm{~min}$ in a continuous reactor operated at $50 \mathrm{~kg} / \mathrm{h}$ feed rate and a straw to water ratio of 1:5. The pretreated fibers were washed and pressed, and stored frozen $\left(-20^{\circ} \mathrm{C}\right)$ in aliquots until use. The dry matter (DM) content of the defrosted material was $34.0 \%$ as determined after overnight drying at $105{ }^{\circ} \mathrm{C}$. The insoluble solids content was $97.5 \%$ of the DM. The carbohydrate composition of the solids was analyzed after total acid hydrolysis by HPLC (Puls et al., 1985; Tenkanen and Siika-aho, 2000). Monosaccharide sugars from the acid hydrolysate were analyzed by HPLC using Dionex system as described by Tenkanen and Siika-aho (2000). The glucan content of the solids was $58.9 \%$ of DM comprising $94 \%$ of all carbohydrates. The major hemicellulose sugar was xylose (3.6 \% of DM).

\subsection{Enzymes}

For developing the viscometric method, commercial cellulase preparations;

Celluclast 1.5L and Novozym 188 (Novozymes A/S, Bagsværd, Denmark) were used to obtain enzymatic liquefaction. The filter paper activity (FPA) of Celluclast was 49 filter paper units (FPU) per $\mathrm{ml}$ according to the standardized filter paper assay of IUPAC (Ghose, 1987). The $\beta$-glucosidase activity of Novozym was $6360 \mathrm{nkat} / \mathrm{ml}$ ( 380 IU/ml) as assayed by measuring the release of $p$-nitrophenol from $p$-nitrophenyl- $\beta-D$ glucopyranoside (PNPG) (Bailey and Nevalainen, 1981). The activities were determined at $\mathrm{pH} 5.0$ and $50{ }^{\circ} \mathrm{C}$. The protein contents of Celluclast and Novozym were $134 \mathrm{mg} / \mathrm{ml}$ and $79 \mathrm{mg} / \mathrm{ml}$, respectively. 
To study the enzymatic mechanisms of the liquefaction, the major hydrolytic enzymes of Trichoderma reesei purified from culture filtrates were used: CBHI ( Cel7A) as described by Rahkamo et al. (1996), CBHII (Cel6A), EGI (Cel7B), EGII (Cel5A) as described by Suurnäkki et al. (2000), EGIII (Cel12A) as described by Karlsson et al. (2002), and xylanase (XYL) XYLII (Xyn11A) as described by Tenkanen et al. (1992) but omitting the last gel filtration stage. The activities of the preparations were determined at $\mathrm{pH} 5.0$ and reported as nkat/ml. EG activity was assayed as the release of reducing sugars from hydroxyethyl cellulose (HEC) using 2,4-dinitrosalicylic acid (DNS) according to the IUPAC procedure (Ghose, 1987). $\beta$-glucanase activity was assayed as EG activity but replacing HEC by barley $\beta$-glucan as substrate. $\mathrm{CBH}$ activity was measured against $1 \mathrm{mM}$ 4-methylumbelliferyl- $\beta$ - $D$-lactoside (MUL) using $100 \mathrm{mM}$ glucose as $\beta$-glucosidase inhibitor and subtracting the activity due to other enzymes (detected in the presence of $5 \mathrm{mM}$ cellobiose) from the value obtained without cellobiose inhibition (van Tilbeurgh et al., 1982). Xylanase activity was determined according to Bailey et al. (1992) using birchwood xylan as substrate. Mannanase activity was assayed according to Stålbrandt et al. (1993). Protein content was determined with the Bio-Rad Protein Assay (Bio-Rad Laboratories, Hercules, CA, USA) using bovine serum albumin as standard. Prior to the protein assay from commercial preparations the proteins were precipitated by $10 \%(\mathrm{w} / \mathrm{w})$ trichloroacetic-acid.

\subsection{Viscometric (RVA) method}

Liquefaction studies were carried out in a microprocessor-controlled rotational viscometer, Rapid Visco Analyzer (RVA), model RVA-4 instrument (Newport Scientific Pty Ltd., Warriewood, NSW, Australia) operated from PC with Thermocline 
for Windows software (TCW, Version 2.2). The viscosity standard used for calibration of RVA was S2000 Oil nominal $5000 \mathrm{cP}$ and the viscosity accuracy was $+/-3 \%$. The sample was loaded in a disposable aluminum canister, which was placed and tightly clamped in the temperature-controlled copper block of the instrument. The construct allows consistent thermal contact and rapid heat transfer between the block, which was mixed throughout the test by a plastic paddle immersed from the top. Enzymatic liquefaction trials were carried out in $25-50 \mathrm{~g}$ of $15 \%(\mathrm{w} / \mathrm{w}, \mathrm{DM})$ wheat straw suspension in $0.05 \mathrm{M}$ sodium-citrate buffer ( $\mathrm{pH}$ 5.0) at $50{ }^{\circ} \mathrm{C}$. Because of the highsolids content the suspension was prepared on weight basis and measured directly into the aluminum container that accommodated the reaction. After setting the test profile (reaction temperature, agitation speed, test time) reaction was started and the viscosity of the sample was detected through continuous monitoring of the torque required to maintain the paddle speed at the set value. The set temperature $\left(50 \pm 0.5^{\circ} \mathrm{C}\right)$ was reached in the bulk material within 2 minutes after the start of the reaction. The temperature was thereafter kept constant with high accuracy $\left(50 \pm 0.04{ }^{\circ} \mathrm{C}\right)$ as detected through the temperature of the thermal block. Apparent viscosities $(\mathrm{cP})(1 \mathrm{cP}=1 \mathrm{mPa} \cdot \mathrm{s})$ were read at intervals of $4 \mathrm{~s}$ and recorded by PC. The reproducibility of the system was verified in five parallel tests.

For developing and optimizing the method, the trials were initialized with preincubating the substrate for $1 \mathrm{~h}$ at the set mixing speed (20-400 rpm) and after the addition of the enzymes (0.5-5 FPU Celluclast, 0.5-5 IU Novozym, per g solids DM) the reaction was monitored for an additional $1 \mathrm{~h}$. When studying the purified T. reesei enzymes, no pre-incubation was employed; after the thermal block reached the set 
temperature, the reaction was started by the addition of the enzyme and incubated at $50{ }^{\circ} \mathrm{C}$ with mixing $(100 \mathrm{rpm})$ for $1.5 \mathrm{~h}$. The various families of enzymes were evaluated and compared for their capability to decrease the viscosity (or increase the flowability) of the substrate suspension at a constant protein dosage of $3 \mathrm{mg}$ per g dry substrate. To avoid possible end product inhibition by cellobiose, the reaction mixture was supplemented by $\beta$-glucosidase (300 nkat of Novozym 188 per g dry substrate). The efficiency of a lower enzyme dosage ( $1.5 \mathrm{mg}$ per g dry substrate) or tailored enzyme mixtures were studied in a similar experimental configuration, except that no $\beta$-glucosidase was used. In all cases, the added enzyme was made up with buffer to a standard volume, bringing the suspension to the target solids content (15\%) and full reaction load $(25-50 \mathrm{~g})$.

\subsection{Analysis of hydrolysis products}

The liquefaction experiments by purified T. reesei enzymes were terminated after $1.5 \mathrm{~h}$ and the reaction mixtures were immediately sampled. The hydrolytic reaction in the withdrawn samples was stopped by inactivating the enzymes by boiling for $10 \mathrm{~min}$. The samples were prepared according to the method of Kristensen et al. (2008) for the analysis of high-solids biomass suspensions. Three representative aliquots (3-5 g) of the reaction mixture were transferred to pre-weighed Falcon tubes, which were thereafter closed, boiled for $10 \mathrm{~min}$, cooled to room temperature, and weighed. After approx 10-times dilution with water the tubes were weighed again and the exact dilutions were calculated. Clear supernatants of the diluted samples were analyzed for reducing sugars by the dinitrosalicylic acid method of Miller (1959) using $D$-glucose as standard and 
stored at $-20{ }^{\circ} \mathrm{C}$ for further sugar analysis by gas chromatography (GC-FID) using Agilent 6890N system and Agilent HP-5 column (Blakeney, 1983).

Alternatively, to check the hydrolytic performance of individual enzymes in the saccharification stage, the reaction mixtures collected after $1.5 \mathrm{~h}$ of liquefaction were transferred to 50-ml flasks for an elongated hydrolysis in a shaking incubator (200 rpm, $\left.50{ }^{\circ} \mathrm{C}, 48 \mathrm{~h}\right)$. The samples collected after $48 \mathrm{~h}$ were assayed for sugar content as described above. To avoid loss of sugars due to possible microbial contamination, the buffer used to prepare the substrate of these longer-running experiments contained $0.02 \%$ $\mathrm{NaN}_{3}$.

\section{Results and Discussion}

In order to identify the key enzyme(s) responsible for the reduction of viscosity in the liquefaction of the lignocellulosic substrate, pretreated wheat straw, the well-known enzymes of the industrially relevant mesophilic fungus Trichoderma reesei were selected as source of enzymes representing different glycosyl hydrolase families. The Rapid Visco Analyzer, which can easily handle high-viscosity materials and is a widely used instrument for determining the viscometric properties of starch, flour and whole grain, was employed for working at high-solids. The technique was applied to investigate the liquefaction efficiency of various enzymes. The viscometric studies were not extended to investigate the true material properties of the saccharifying biomass.

\subsection{RVA methodology using commercial enzymes}


The RVA was used to monitor the decrease of viscosity, i.e. the increase of the flowability of the straw substrate. In conventional methods using the RVA equipment for rheological studies of e.g. starch, typically samples of 3-5 g suspended in $25 \mathrm{ml}$ of water are used. In accordance with this, the first set of experiments was carried out at $25 \mathrm{~g}$ total reaction load (Figure 1A). The method produced a clear baseline during the first 60 min of the RVA tests and the enzymatic liquefaction was easy to detect in the experimental system as the viscosity decreased after the addition of enzymes at $60 \mathrm{~min}$. To increase the sensitivity of the method for easier comparability of enzymes with similar liquefaction profiles and to observe even small changes in the flowability of the material in response to the enzymatic action, different parameters were studied. A more stable baseline was achieved with higher reaction volume (Figure 1B), which was found advantageous because the system became less sensitive to disturbances caused by the non-homogenous nature of the substrate. In contrast, there was a steady increase in the noise of the baseline signal as the agitation speed was decreased (Figure 1C). Therefore, low agitation speeds were not considered beneficial although the more pronounced decrease of the apparent viscosity observed at lower speeds would have been favorable. Finally, dose-response studies confirmed that the system was able to distinguish enzymes with different liquefaction efficiencies on the substrate (Figure 1D). In spite of the remarkable signal noise during the course of the measurement, the method showed good reproducibility in five parallel tests (Figure 2).

In general, the apparent viscosity decreased with increasing agitation rates, which is typical for shear-thinning fluids. The viscosity of wheat straw decreased rapidly with the reaction time as the hydrolysis progressed, and the change was most pronounced 
during the first 20 minutes. Obviously, the various parameters affect the viscosity values $(\mathrm{cP})$ obtained and it is therefore difficult to set a target value or to compare these values with previous results. The viscosity of $5-15 \%(\mathrm{w} / \mathrm{w})$ barley straw in fed-batch hydrolysis using commercial cellulases has been followed by Rosgaard et al. (2007) resulting in a similar significant reduction of viscosity.

As a conclusion of the results obtained for the optimization of the method, the standard procedure used in further experiments employed $50 \mathrm{~g}$ of $15 \%(\mathrm{w} / \mathrm{w})$ suspension (DM) of hydrothermally treated wheat straw, agitation speed of $100 \mathrm{rpm}$, reaction temperature of $50{ }^{\circ} \mathrm{C}$ and the reaction was followed up to $1.5 \mathrm{~h}$.

\subsection{Viscosity studies with purified T. reesei enzymes}

The major hydrolytic enzymes of Trichoderma reesei, representing different families, were investigated to understand the fundamental role of various types of enzymes acting on lignocellulose in the reduction of viscosity during lignocellulose liquefaction. The purified enzymes comprised the two cellobiohydrolases: CBHI (Cel7A) and CBHII (Cel6A), three endoglucanases: EGI (Cel 7B), EGII (Cel 5A), and EGIII (Cel 12A), and the xylanase XYLII (Xyn 11A). The protein contents and key activities of the preparations are listed in Table 1 . Because of the different activity patterns, the enzymes were dosed on the protein basis.

The efficiency of the enzymes to liquefy wheat straw differed significantly (Figure 3). The commercial $\beta$-glucosidase (Novozym 188) alone had no effect on the viscosity of the material and therefore it was concluded that the liquefaction patterns obtained by the 
set of investigated enzymes were not affected by the added $\beta$-glucosidase preparation at the low degree of hydrolysis. As expected, the endoglucanases I, II and III (Figures 3A, 3B, 3C) had a more pronounced effect on the viscosity than the cellobiohydrolases (Figure 3D) or the xylanase (Figure 3E) preparation alone. In particular, EGII (Cel5A) proved to liquefy the biomass most rapidly and efficiently. Also EGI (Cel 7B) was fairly efficient, but did not reach the same low viscosity level than EGII. Previously, it has been shown that the activity of EGIII (Cel12A) on cellulose substrates is significantly lower than those of EGI and EGII (Karlsson et al., 2002). The size of EGIII is clearly smaller (23 kDa) than those of EGI and EGII (55 and $48 \mathrm{kDa}$ ) and it has been speculated that the small enzyme would be able to penetrate the small pores not accessible to larger enzymes. However, in spite of the higher molar dosage, the EGIII was clearly the least effective, expectedly due to the lack of a cellulose binding module (Karlsson et al., 2002). The specific activities of the EGs against the artificial soluble substrate (HEC) differed significantly, but were in accordance with the final viscosity values obtained, being lowest with the EGII. The EGs are generally known to preferably act on the amorphous, water-binding parts of the cellulose fibers (Oksanen et al., 2000). The decrease of viscosity is suggested to be strongly connected with the degradation and decrease of water binding capacity of the lignocellulose structures during the enzymatic action (Viamajala et al., 2009), which can explain the superior liquefying performance of the EGs. Oksanen et al. (2000) also observed a significant decrease of kraft pulp viscosity by EG's but no significant change in the water retention values could be observed. After the enzymatic liquefaction, a clear difference could be visualized in the texture, i.e. the amount of free water of the substrate. This obviously 
reflects the differences in particle shapes and sizes and particle size distribution between kraft pulp and pretreated wheat straw.

The use of tailored enzyme mixture mimicking common commercial preparations (60\% CBHI, 20\% CBHII, 8\% EGI, 8\% EGII, 1.5\% EGIII, 2.5\% XYLII) did not result in improved decrease of viscosity during the liquefaction (Figure 3F). This can be explained by the fact that the cocktail contained a relatively low amount of EGs, and contained only $8 \%$ of the key liquefying enzyme EGII (Cel5A). In contrast, the level of hydrolysis (as \% of reducing sugars released from the theoretically available in the substrate) obtained by the mixture was much higher than that obtained by the single enzymes (Table 2). This is consistent with previous reports on the synergistic hydrolytic behaviour of lignocellulose degrading enzymes (Henrissat et al., 1985, Baker et al., 1998).

As expected, the overall hydrolytic efficiencies using single enzymes were low. The level of hydrolysis, in general, did not correlate with the decrease of viscosity obtained in the same reaction (Table 2), suggesting that liquefaction (reduction of viscosity) is more dependent on the site than the frequency of enzymatic cleavages. Pure CBHI and the EGs I and II released roughly the same amounts of soluble sugars in $1.5 \mathrm{~h}$ hydrolysis. It is important to note, however, that the level of hydrolysis was determined on the basis of solubilization of reducing sugars, which does not measure the eventual increase of reducing ends in the solid material. On the other hand, the amount of reducing sugars was increased only slightly by the endoglucanases after the first 1.5 hours as compared 
with the cellobiohydrolases, which increased the sugar yield relatively more during the prolonged hydrolysis.

Results by gas chromatography (data not presented) on the amount of total identified monomeric sugars after $1.5 \mathrm{~h}$ of hydrolysis were in good agreement with the DNS analysis data. The solubilised sugars produced by the cellulases were mainly recovered as glucose because of the presence of $\beta$-glucosidase. Thus, the previously observed selectivity in the product profiles of the different T. reesei endoglucanases (Enebro et al., 2009) could not be observed. Xylose and other sugars were detected at a level lower of at least an order of magnitude. It was, however, clearly seen that among the studied endoglucanases EGI produced the highest amount of xylose from the substrate, which is consistent with previous observations on the xylanase activity of EGI (Zurbriggen et al., 1991; Suurnäkki et al., 2000). The product profile of the studied xylanase differed significantly from that of the cellulases; after $1.5 \mathrm{~h}$ of hydrolysis XYLII solubilised approx $10 \%$ of the available xylan. The amount of xylose formed by XYLII $(0.5 \mathrm{mg} / \mathrm{ml}$, $10 \%$ of xylan in substrate) was in the same range as that released by EGI $(0.3 \mathrm{mg} / \mathrm{ml}, 6 \%$ of xylan in substrate). The release of monomeric xylose may have been limited because of the lack of $\beta$-xylosidase in the enzyme cocktail.

The combined liquefying effect of enzymes acting in concert was studied with the previously developed RVA method using EGII (Cel5A) as the key enzyme in twocomponent mixtures at a decreased total enzyme dosage (Figure 4). These studies were carried out without $\beta$-glucosidase (Novozym 188) addition because the relatively short hydrolysis time and low conversion levels - concluded from the previous experiments - 
were not expected to inhibit the hydrolysis. Replacing one third of the key liquefying enzyme EGII by the other major hydrolytic enzymes; endoglucanases I or III (Figure 4A), cellobiohydrolases I or II (Figure 4B) or xylanase (Figure 4C) did not further improve the liquefaction as compared to the control containing EGII alone. Based on these results no synergism could be observed between the enzymes in the liquefaction as measured by the viscosity drop. The possible synergistic effects by the added enzymes did not compensate the decreased amount of EGII in the mixtures. Further experiments would be needed to study the combined effects of liquefying and hydrolyzing actions of various enzymes and to optimize the overall efficiency of the two-step hydrolytic process.

\section{Conclusion}

The RVA viscometry was applied to follow the initial steps of enzymatic hydrolysis and to evaluate the liquefaction efficiency of various hydrolytic enzymes. Using a set of purified enzymes from Trichoderma reesei, endoglucanases proved to have distinguished capability to rapidly reduce the viscosity of the substrate in high-solids lignocellulose treatments. Liquefaction efficiencies did not, however, correlate with the hydrolytic performances of enzymes when applied individually or in concert. Therefore, process optimization should not only focus on minimized enzyme use but also on the optimized combination of enzymes with good liquefying or hydrolytic efficiencies in the relevant processing steps.

\section{Acknowledgements}


The research leading to present results was funded by the EC's 7th Framework Program (FP7/20072013) under grant agreement no. 213139. Inbicon A/S (Fredericia, Denmark) is acknowledged for supplying the pretreated substrate. 


\section{References}

Bailey, M., Biely, P., Poutanen K., 1992. Interlaboratory testing of methods for assay of xylanase activity. J. Biotechnol. 23(3), 257-270.

Bailey, M.J., Nevalainen, H., 1981. Induction, isolation and testing of stable Trichoderma reesei mutants with improved production of solubilizing cellulase. Enzyme Microb. Technol. 3(2), 153-157.

Baker, J.O., Ehrman, C.I., Adney, W.S., Thomas, S.R., Himmel, M.E., 1998.

Hydrolysis of cellulose using ternary mixtures of purified cellulases. Appl. Biochem. Biotechnol. 70-72, 395-403.

Blakeney, A.B., Harris, P.J., Henry, R.J., Stone, B.A., 1983. A simple and rapid preparation of alditol acetates for monosaccharide analysis. Carbohyd. Res. 113(2), 291-299.

Dasari, R.K., Berson, R.E., 2007. The effect of particle size on hydrolysis reaction rates and rheological properties in cellulosic slurries. Appl. Biochem. Biotechnol. 137, 289-299.

Ehrhardt, M.R., Monz, T.O., Root, T.W., Connelly, R.K., Scott, C.T., Klingenberg, D.J., 2010. Rheology of dilute acid hydrolyzed corn stover at high solids concentration. Appl. Biochem. Biotechnol. 160(4), 1102-1115.

Enebro, J., Momcilovic, D., Siika-aho, M., Karlsson, S., 2009. Liquid chromatography combined with mass spectrometry for the investigation of endoglucanase selectivity on carboxymethyl cellulose. Carbohydr. Res. 344, 2173-2181. 
Georgieva, T.I., Hou, X., Hilstrøm, T., Ahring, B.K., 2008. Enzymatic hydrolysis and ethanol fermentation of high dry matter wet-exploded wheat straw at low enzyme loading. Appl. Biochem. Biotechnol. 148(1-3), 35-44.

Ghose, T.K., 1987. Measurement of cellulase activities. Pure Appl. Chem. 59(2), $257-268$.

Hahn-Hägerdal, B., Galbe, M., Gorwa-Grauslund, M.F., Lidén, G., Zacchi, G., 2006. Bio-ethanol - the fuel of tomorrow from the residues of today. Trends Biotechnol. 24(12), 549-556.

Henrissat, B., Driguez, H., Viet, C., Schülein, M., 1985. Synergism of cellulases from Trichoderma reesei in the degradation of cellulose. Bio/Technology 3, 722-726.

Houchin, T.L., Hanley, T.R., 2004. Measurement of rheology of distiller's grain slurries using a helical impeller viscometer. Appl. Biochem. Biotechnol. 113, 723-732. Jørgensen, H., Vibe-Pedersen, J., Larsen, J., Felby, C., 2007. Liquefaction of lignocellulose at high-solids concentrations. Biotechnol. Bioeng. 96(5), 862-870. Karlsson, J., Siika-aho, M., Tenkanen, M., Tjerneld, F., 2002. Enzymatic properties of the low molecular mass endoglucanases Cel12A (EG III) and Cel45A (EG V) of Trichoderma reesei. J. Biotech. 99, 63-78.

Knutsen, J.S., Liberatore, M.W., 2009. Rheology of high-solids biomass slurries for biorefinery applications. J. Rheol. 53(4), 877-892.

Kristensen, J.B., Felby, C., Jørgensen, H., 2008. Determining yields in high solids enzymatic hydrolysis of biomass. Appl. Biochem. Biotechnol. 156(1-3), 557-562. Larsen, J., Petersen, M.Ø., Thirup, L., Li, H.W., Iversen, F.K., 2008. The IBUS Process - Lignocellulosic bioethanol close to a commercial reality. Chem. Eng. Technol. 31(5), $765-772$. 
Miller, G.L., 1959. Use of dinitrosalicylic acid reagent for determination of reducing sugars. Anal. Chem. 31(3), 426-428.

Oksanen, T., Pere, J., Paavilainen, L., Buchert, J., Viikari, L., 2000. Treatment of recycled kraft pulps with Trichoderma reesei hemicellulases and cellulases. J. Biotech. $78,39-48$.

Pimenova, N.V., Hanley, T.R., 2004. Effect of corn stover concentration on rheological characteristics. Appl. Biochem. Biotechnol. 114, 347-360.

Puls, J., Poutanen, K., Körner, H.-U., Viikari, L., 1985. Biotechnical utilization of wood carbohydrates after steaming pretreatment. Appl. Microbiol. Biotechnol. 22, 416-423. Rahkamo, L., Siika-aho, M., Vehviläinen, M., Dolk, M., Viikari, L., Nousiainen, P., Buchert, J., 1996. Modification of hardwood dissolving pulp with purified Trichoderma reesei cellulases. Cellulose 3(1), 153-163.

Roche, C.M., Dibble, C.J., Knutsen, J.S., Stickel, J.J., Liberatore, M.W., 2009. Particle concentration and yield stress of biomass slurries during enzymatic hydrolysis at highsolids loadings. Biotechnol. Bioeng. 104(2), 290-300.

Rosgaard, L., Andric, P., Dam-Johansen, K., Pedersen, S., Meyer, A.S., 2007. Effects of substrate loading on enzymatic hydrolysis and viscosity of pretreated barley straw. Appl. Biochem. Biotechnol. 143(1), 27-40.

Stålbrandt, H., Siika-aho, M., Tenkanen, M., Viikari, L., 1993. Purification and characterization of two $\beta$-mannanases from Trichoderma reesei. J. Biotechnol. 29, $229-242$.

Stickel, J.J., Knutsen, J.S., Liberatore, M.W., Luu, W., Bousfield, D.W., Klingenberg, D.J., Scott, C.T., Root, T.W., Ehrhardt, M.R., Monz, T.O., 2009. 
Rheology measurements of a biomass slurry: an inter-laboratory study. Rheol. Acta 48(9), 1005-1015.

Suurnäkki, A., Tenkanen, M., Siika-aho, M., Niku-Paavola, M.-L., Viikari, L, Buchert, J., 2000. Trichoderma reesei cellulases and their core domains in the hydrolysis and modification of chemical pulp. Cellulose 7, 189-209.

Tenkanen, M., Puls, J., Poutanen, K., 1992. Two major xylanases of Trichoderma reesei. Enzyme Microb. Technol. 14, 566-574.

Tenkanen, M., Siika-aho, M, 2000. An $\alpha$-glucuronidase of Schizophyllum commune acting on polymeric xylan. J. Biotechnol. 78(2), 149-161.

Thomas, K.C., Ingledew, W.M., 1992. Production of $21 \%(\mathrm{v} / \mathrm{v})$ ethanol by fermentation of very high gravity (VHG) wheat mashes. J. Ind. Microbiol. 10, 61-68.

van Tilbeurgh, H., Claeyssens, M., de Bruyne, C.K., 1982. The use of 4-methylumbelliferyl and other chromophoric glycosides in the study of cellulolytic enzymes. FEBS Lett. 149(1), 152-156.

Varga, E., Klinke, H.B., Réczey, K., Thomsen, A.B., 2004. High solid simultaneous saccharification and fermentation of wet oxidized corn stover to ethanol. Biotechnol. Bioeng. 88(5), 567-574.

Viamajala, S., McMillan, J.D., Schell, D.J., Elander, R.T., 2009. Rheology of corn stover slurries at high solids concentrations - Effects of saccharification and particle size. Bioresource Technol. 100, 925-934.

Viikari, L., Alapuranen, M., Puranen, T., Vehmaanperä, J, Siika-aho, M., 2007. Thermostable enzymes in lignocellulose hydrolysis. Adv. Biochem. Engin. Biotechnol. $108,121-145$. 
Zacchi, G., Axelsson, A., 1989. Economic evaluation of preconcentration in production of ethanol from dilute sugar solutions. Biotechnol. Bioeng. 34(2), 223-233.

Zurbriggen, B., Penttilä, M., Viikari, L., Bailey, M., 1991. Pilot scale production of a

Trichoderma reesei endo-beta-glucanase by brewer's yeast. J. Biotechnol., 17, 133-146. 
Table 1. Activities and protein contents of purified enzymes from $T$. reesei used in the liquefaction studies.

\begin{tabular}{|c|c|c|c|c|c|c|}
\hline \multirow{3}{*}{ Enzymes } & \multirow{2}{*}{\multicolumn{5}{|c|}{$\begin{array}{l}\text { Activities } \\
\text { (nkat/ml) }\end{array}$}} & \multirow{3}{*}{$\begin{array}{l}\text { Protein } \\
(\mathrm{mg} / \mathrm{ml})\end{array}$} \\
\hline & & & & & & \\
\hline & EG & $\mathrm{CBH}$ & $\beta$-glucanase & Xylanase & Mannanase & \\
\hline CBHI / Cel7A & 0 & 27.3 & 0.75 & n.d. & n.d. & 12.2 \\
\hline CBHII / Cel6A & $<1$ & 0 & 71 & 1.2 & 2.1 & 3.0 \\
\hline EGI / Cel7B & 2254 & n.d. & n.d. & n.d. & n.d. & 4.65 \\
\hline EGII / Cel5A & 6886 & n.d. & n.d. & n.d. & n.d. & 7.54 \\
\hline EGIII / Cel12A & 370 & n.d. & n.d. & n.d. & n.d. & 3.36 \\
\hline XYLII / Xyn11A & n.d. & n.d. & n.d. & 31000 & n.d. & 3.2 \\
\hline
\end{tabular}


Table 2. Viscosities and soluble sugars (based on DNS analysis) after 1.5 h RVA treatment $\left(100 \mathrm{rpm}, 50{ }^{\circ} \mathrm{C}\right)$ followed by extended hydrolysis for $48 \mathrm{~h}$ in shake flasks $\left(200 \mathrm{rpm}, 50{ }^{\circ} \mathrm{C}\right)$ using $15 \%$ (w/w) hydrothermally pretreated wheat straw and $3 \mathrm{mg}$ of T. reesei enzymes supplemented with 300 nkat Novozym per g dry substrate. The mixture (3 mg/g DM) contained 60\% CBHI, 20\% CBHII, 8\% EGI, 8\% EGII, 1.5\% EGIII, and 2.5\% XYLII on weight basis. The control contained $300 \mathrm{nkat} / \mathrm{g}$ DM Novozym only.

\begin{tabular}{lcllc}
\hline Enzymes & \multicolumn{2}{l}{ Viscosity $(\mathrm{cP})$} & \multicolumn{2}{l}{ Reducing sugars } \\
& & (average of readings at $85-90 \mathrm{~min})$ & \multicolumn{2}{l}{ (\% of total carbohydrates) } \\
\cline { 3 - 5 } & & & $1.5 \mathrm{~h}$ & $48 \mathrm{~h}$ \\
& & & $5.2 \pm 0.19$ & $8.6 \pm 0.39$ \\
\hline CBHI / Cel7A & 6206 & \pm 167 & $4.8 \pm 0.22$ & $6.7 \pm 0.20$ \\
CBHII / Cel6A & 4860 & \pm 300 & $5.4 \pm 0.21$ & $6.8 \pm 0.36$ \\
EGI / Cel7B & 1608 & \pm 18 & $5.7 \pm 0.02$ & $6.8 \pm 1.15$ \\
EGII / Cel5A & 928 & \pm 7 & $2.9 \pm 0.87$ & $4.5 \pm 0.41$ \\
EGIII / Cel12A & 2389 & \pm 159 & $2.7 \pm 0.51$ & $3.1 \pm 0.88$ \\
XYLII / Xyn11A & 7371 & \pm 372 & $9.6 \pm 0.36$ & $20.1 \pm 0.15$ \\
Mixture & 1337 & \pm 18 & $3.4 \pm 0.01$ & $3.6 \pm 0.03$ \\
Control & 7844 & \pm 302 & &
\end{tabular}




\section{Figure Captions}

Figure 1 . The effect of various parameters on the viscosity using $15 \%(\mathrm{w} / \mathrm{w})$

hydrothermally treated wheat straw as substrate in $0.05 \mathrm{M}$ sodium-citrate buffer ( $\mathrm{pH}$ 5.0)

in the Rapid Visco Analyzer at $50{ }^{\circ} \mathrm{C}$. After $1 \mathrm{~h}$ of pre-incubation Celluclast and

Novozym 188 (0.5-5 FPU and 0.5-5 IU/g substrate, respectively) were added and the reaction was monitored for additional $1 \mathrm{~h}$. (A): agitation speed (200 rpm - $400 \mathrm{rpm})$ at $25 \mathrm{~g}$ total reaction load and using 5 FPU Celluclast and 5 IU Novozym 188, (B): reaction volume at $400 \mathrm{rpm}$ (enzymes as previously), (C): agitation speed (20 rpm $400 \mathrm{rpm}$ ) at $50 \mathrm{~g}$ reaction load (enzymes as previously), (D): enzyme dosage (50 g, $400 \mathrm{rpm})$.

Figure 2. The reproducibility of the viscometric technique determined by monitoring the viscosity of pretreated wheat straw (15\% (w/w) in $0.05 \mathrm{M}$ sodium-citrate buffer, $\mathrm{pH} 5.0$, $50 \mathrm{~g}$ scale) during pre-incubation and hydrolysis with Celluclast and Novozym 188 (5 FPU and 5 IU per g solids) at $50{ }^{\circ} \mathrm{C}$ and $100 \mathrm{rpm}$ in five replicate measurements. Averages and standard deviations are shown at $10 \mathrm{~min}$ intervals.

Figure 3. The effect of T. reesei enzymes (A): EGI (Cel7B), (B): EGII (Cel5A), (C): EGIII (Cel12A), (D): CBHI (Cel7A) and CBHII (Cel6A), (E): XYLII (Xyn11A), (F): mixture of 60\% CBHI, 20\% CBHII, 8\% EGI, 8\% EGII, 1.5\% EGIII, 2.5\% XYLII, on the viscosity of $15 \%(\mathrm{w} / \mathrm{w})$ pretreated wheat straw $\left(100 \mathrm{rpm}, 50{ }^{\circ} \mathrm{C}\right)$ using $3 \mathrm{mg}$ enzyme/g substrate DM. For the control, the suspension was made up to the same solids 
content and incubated with mixing without cellulase addition. All reaction mixtures, including control, contained 300 nkat/g DM Novozym 188.

Figure 4. The combined effect of $T$. reesei enzymes $(1.5 \mathrm{mg} / \mathrm{g} \mathrm{DM})$ on the viscosity of $15 \%(\mathrm{w} / \mathrm{w})$ pretreated wheat straw $\left(100 \mathrm{rpm}, 50{ }^{\circ} \mathrm{C}\right)$. The EGII (Cel5A) was used alone or one third $(0.5 \mathrm{mg} / \mathrm{g})$ of EGII was replaced by other enzymes; endoglucanases (A), cellobiohydrolases (B), or xylanase (C). 
Figure 1.
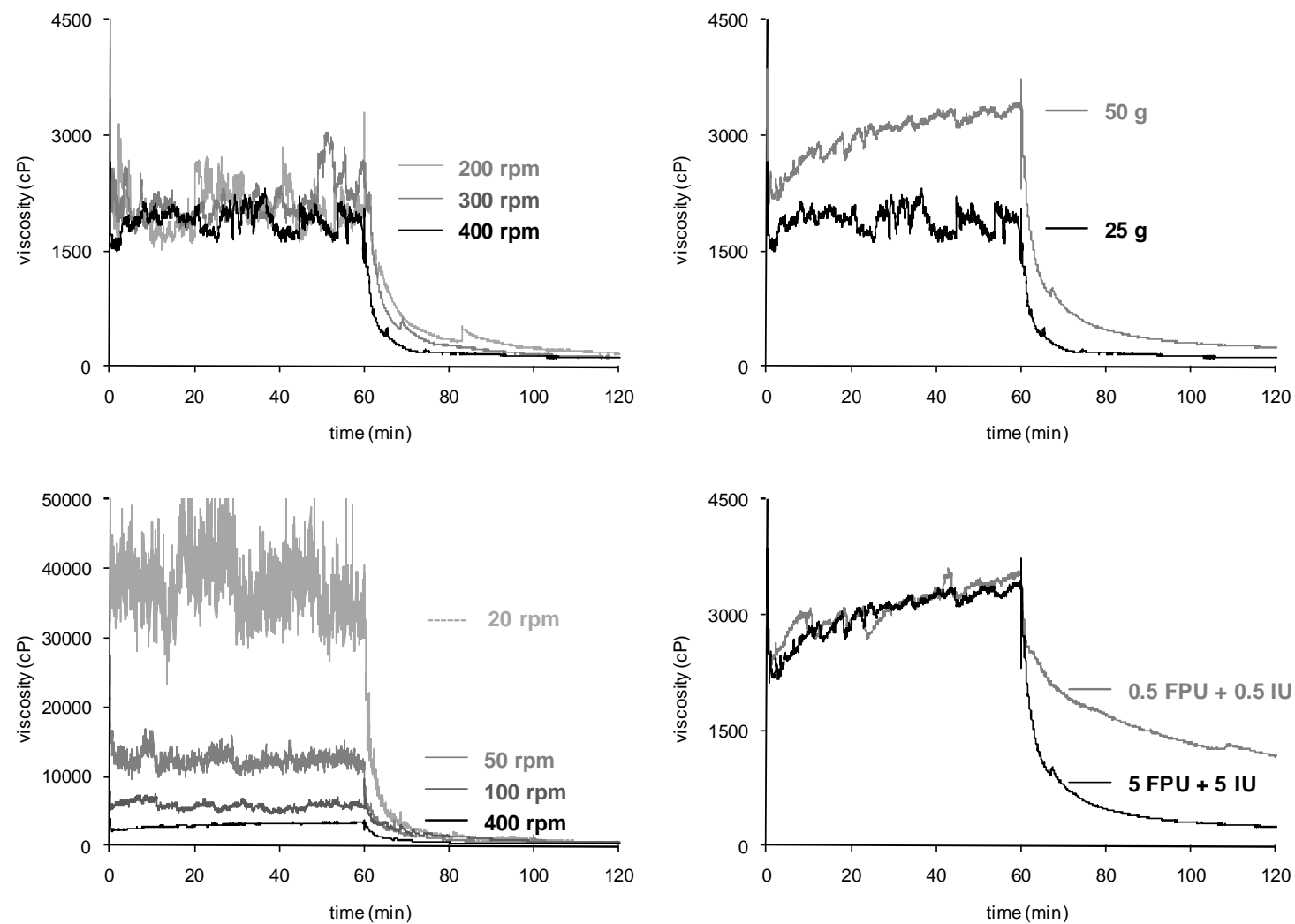
Figure 2.

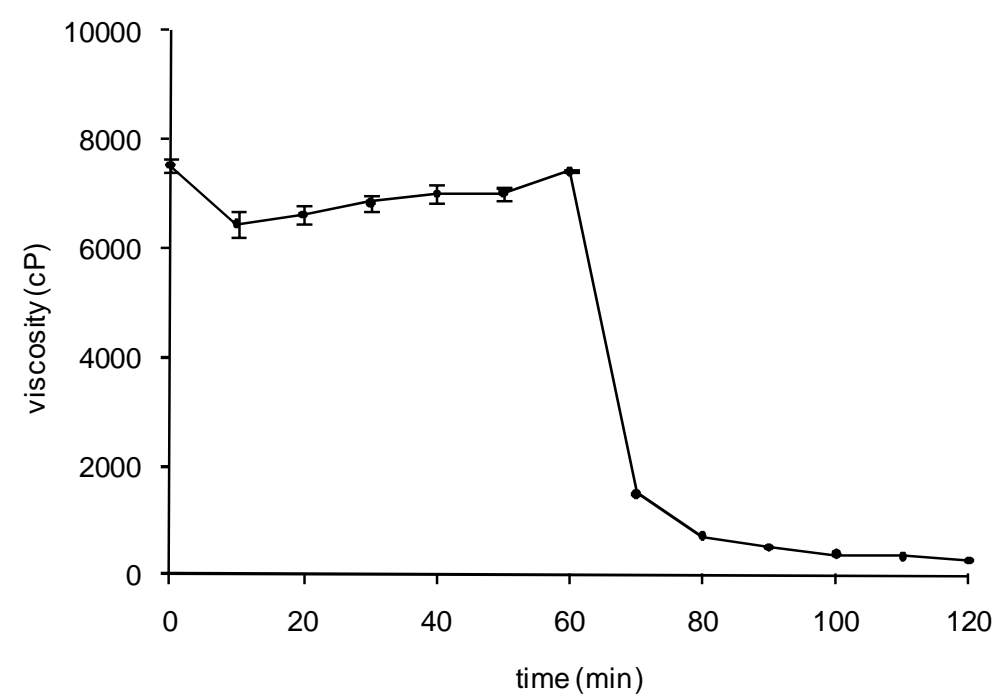


Figure 3.
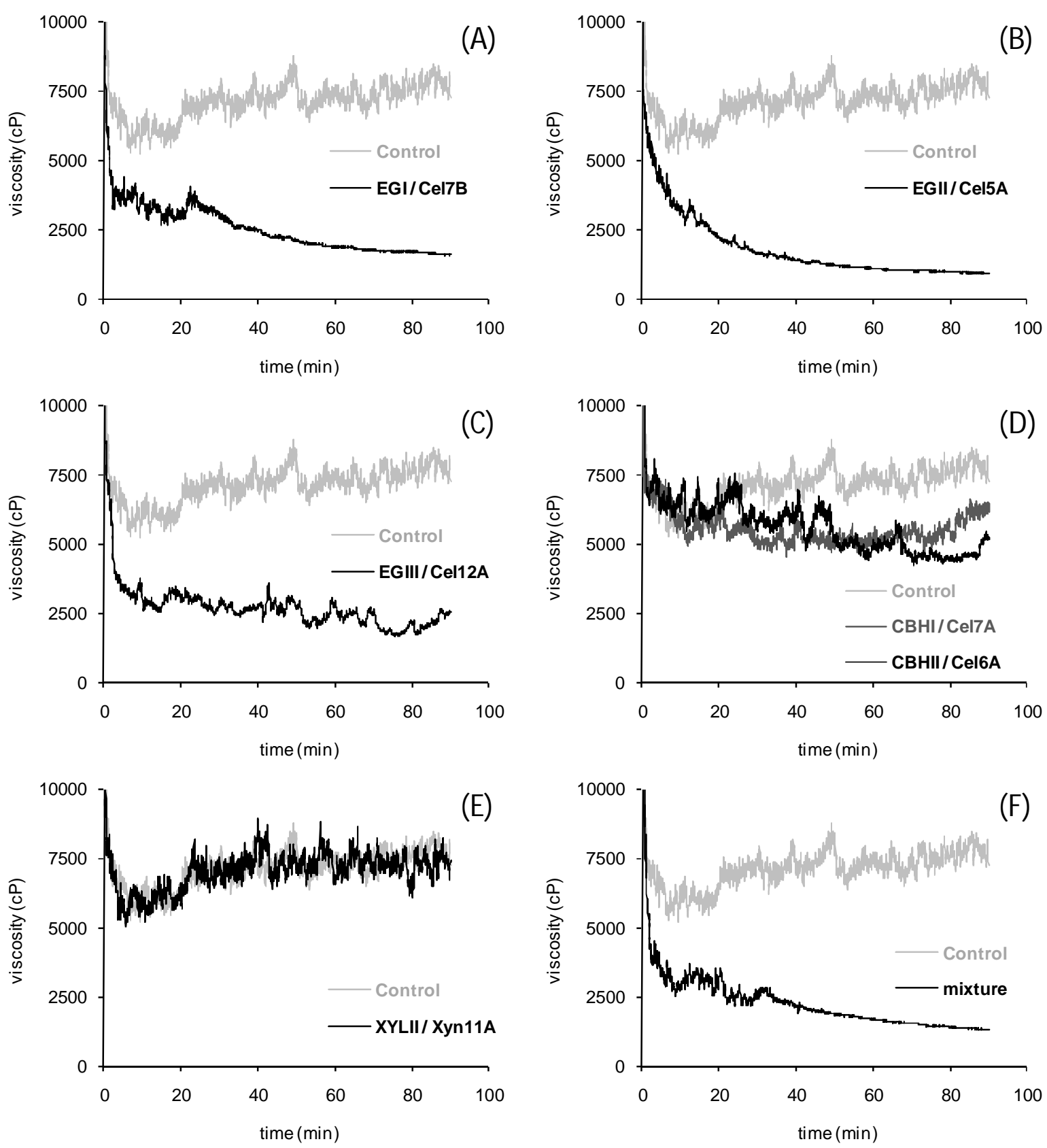
Figure 4.
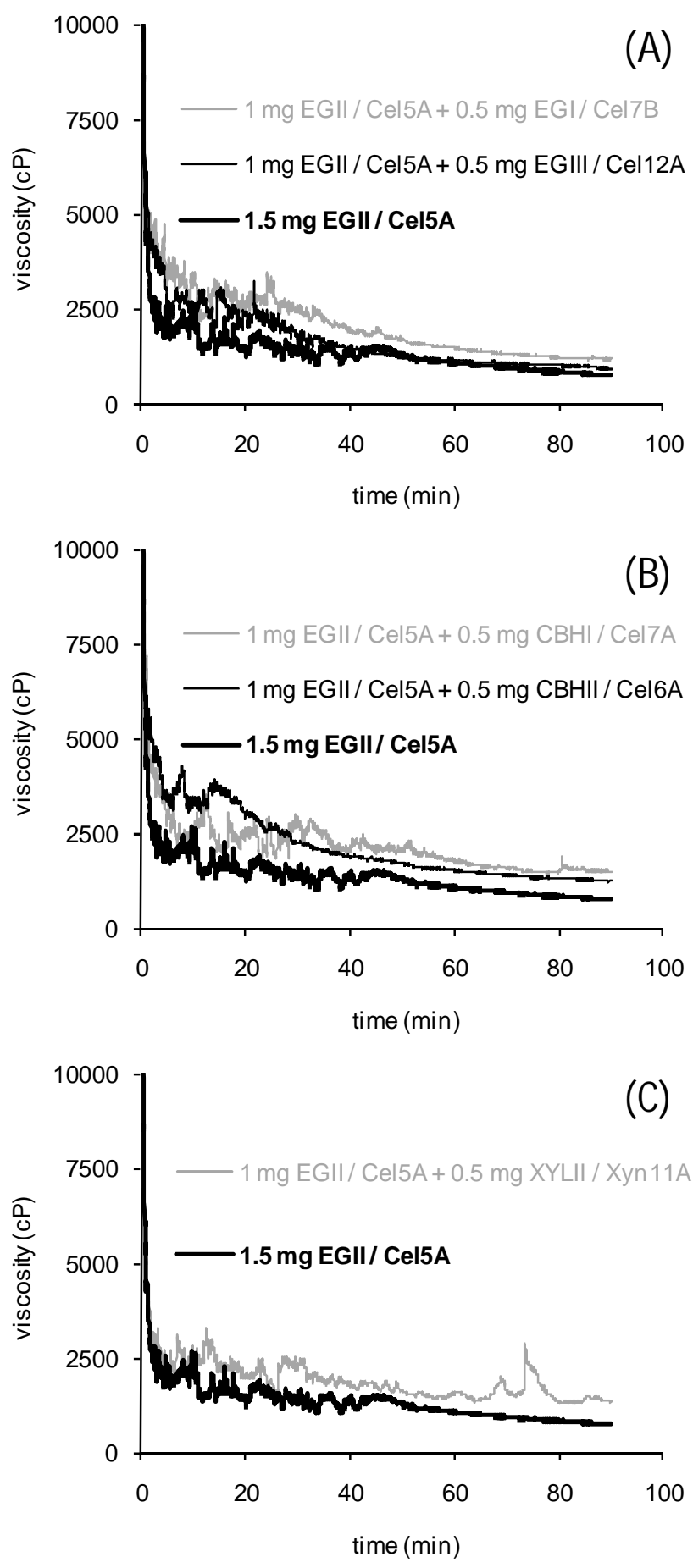